\title{
The state, civil society and social rights in contemporary Russia
}

Eleanor Bindman

School of Politics and International Relations

Queen Mary, University of London

Email: e.bindman@qmul.ac.uk

Address: Arts One, Mile End Road, London E1 4NS

Telephone: 07794160724

\section{Abstract}

This article examines how Russian non-governmental organisations working in the social sector conceptualise the role of the state in guaranteeing social rights and negotiate relations with the state in order to advocate on behalf of the groups they represent. Data is drawn from interviews with representatives of Russian NGOs and state officials. It demonstrates that these organisations see the state as playing a key role in guaranteeing social rights. This facilitates a degree of agency in their relationship with the authorities, who are increasingly keen to use the experience these NGOs provide for service delivery. This challenges the dominant view of compliant and co-opted social NGOs which fully cooperate with the authorities and highlights the need for a more nuanced and complex understanding of statecivil society relations in Russia.

\section{$\underline{\text { Introduction }}$}

The relationship between the Russian authorities and certain domestic civil society actors has long been a fractious one. The introduction in 2012 of a new law requiring domestic nongovernmental organisations (NGOs) in receipt of funding from outside Russia and perceived to be engaging in 'political' activity to register themselves as 'foreign agents' has caused fresh controversy. The law has provoked criticism from international bodies such as the Council of Europe which have expressed concern over a perceived crackdown on civil society activity in Russia (BBC News 2012; Reuters 2013). Much of this controversy has, however, revolved around those NGOs which are engaged explicitly in the promotion of 
issues relating to civil and political rights such as free and fair elections and freedom of speech or in environmental campaigns (RFERL 2013). In contrast, this article considers the interaction between the Russian authorities and NGOs engaged in social work such as providing support to vulnerable children, elderly and disabled people. It also explores how these organisations conceptualise the state's responsibilities in relation to upholding social rights (these include the right to housing, health protection, state-sponsored social security and education which are guaranteed by the Russian Constitution) ${ }^{1}$. This type of organisation and these types of human rights tend to receive far less attention than civil and political rights issues promoted by Russian human rights NGOs, despite being of equal or often greater importance to the general public (Levada Center 2014). Indeed, as Evans (2012) points out, the political and media discussion on Russian civil society which takes places in the West focuses largely on human rights groups, despite the fact that they constitute a very small proportion of Russian civil society organisations. The article begins with a discussion of the relationship between the state and domestic civil society in Russia before exploring the Putin regime's recent practical and rhetorical approach towards social rights and the involvement of certain civil society actors in the delivery of social services. It then presents and analyses findings from a series of interviews with representatives of a range of Russian civil society organisations in four Russian cities between 2011 and 2015. These sought to explore what these organisations perceived the Russian state's obligations to be in relation to guaranteeing social rights and the extent to which they engaged with the authorities in order to advocate for the social rights and entitlements of the groups they claim to represent.

This discussion is situated in the context of both the influence of the centrality of the state in the lives of its citizens in the Soviet period and of more recent government policy. This policy has attempted in part to re-position the state as the key provider of social services but also seeks to delegate considerable responsibility in this area to socially-oriented NGOs. The article addresses the question of how NGOs engaged in various forms of social work interact with the Russian authorities and the impact this may have on their ability to operate independently of the state. The article asks whether this relationship offers socially-oriented NGOs a degree of agency when it comes to advocating for the interests of their constituents. It also seeks to address the question of whether in fact the state may need these NGOs more than the organisations themselves need the authorities' assistance as it attempts to involve

\footnotetext{
${ }^{1}$ The Russian Constitution of 1993 outlined the state's commitment to social rights.
} 
them in the extensive and complex system of social service delivery. It argues that this relationship is considerably more complex and nuanced than the largely antagonistic interaction which tends to take place between these same authorities and NGOs focusing explicitly on human rights issues. The article thus adds to the current debate on the role of socially oriented NGOs within Russian civil society at a time when their activities are of increasing interest to the state.

\section{The state and civil society in Russia}

The classical liberal view of 'civil society' sees this sphere of social relations as one in which a range of formal and informal associations operate independently of the state. They are thus able to act as a counterweight to state institutions, to restrict its authoritarian tendencies, and to provide a space between the individual, the state and the market (Richter 2002; Narozhna 2004; Frohlich 2012). Whether or not these social organisations engage directly in political activity, they are therefore seen according to this formulation as "political and contentious in relation to the state' (Fröhlich 2012: 371) and as a key element in the process of successful democratisation (Henderson 2002). The influence of this approach on foreign funding to Russian NGOs was particularly apparent in the 1990s when Western aid tended to privilege NGOs promoting feminist, environmental and human rights causes who positioned themselves as professional, independent organisations with similar norms and values to their international donors (Evans 2006; Henderson 2002). Yet, as numerous scholars have pointed out, this approach failed to lead to the development of a successful grassroots NGO movement in post-Soviet Russia. Instead it fostered a small, isolated and elitist community of professional advocacy NGOs who focused on campaigns and issues more likely to appeal to their Western donors than their domestic constituents and were dependent on foreign funding for their continued existence (Henderson 2002; McIntosh-Sundstrom 2005; Hemment 2012). By the early 2000s many scholars had reached the conclusion that Russian civil society was weak, ineffective and likely to remain so for some time to come (Morje Howard 2002; Narozhna 2004).

During the period from 2000 onwards, however, when Putin was elected president for the first time, he has sought to reassert and recentralize the power of the Russian state. This has been done in relation to society, business and the relationship between the federal centre and the country's many regions. Lukin (2009: 66) argues that, by the end of Putin's second term 
as president in 2008, a regime had been established in which there were elements of pluralism and democratic procedure such as a constitution and elections. Yet the system retained a high degree of executive control over the parliament, legal system, media and regional authorities - what Hale (2010: 34) describes as a 'hybrid regime' which is neither fully democratic nor fully authoritarian. Where civil society is concerned, this has had important implications. Scholars such as Hale (2002) and Domrin (2002) have contrasted what they see as the Russian government's more 'statist' concept of relations with civil society with the more Western liberal model of the state and civil society as autonomous entities. Under this statist model, state and society are interdependent and cannot be separated into two constituent parts. As a result, non-state society is seen as completing the state rather than diminishing or challenging it. This formulation therefore gives the state a key role in the establishment and activities of civil society organisations.

This statist view therefore gives the state a key role in the activities of non-state social organisations. It is apparently reflected by Putin's decision from 2004 onwards to pursue a policy of creating a 'top-down' model of civil society which rewarded those NGOs deemed to be carrying out socially 'useful' activities with grants and other support. At the same time, those deemed to be pursuing interests or values counter to those of the state, particularly human rights and environmental NGOs, were ostracised (Mohsin Hashim 2005; Henderson 2011).

Where NGOs which focus on tackling specific social problems which affect vulnerable groups in society such as elderly people, disabled people and children in the state care system are concerned, however, broadly speaking these groups have had a rather different and less antagonistic relationship with the authorities (Cook and Vinogradova 2006). Such organisations have been no less a target of state scrutiny than advocacy groups but this scrutiny has taken a very different form. Those organisations engaged in 'social' rather than 'political' work and operating within the Kremlin's 'prescribed boundaries' have been able to apply for large grants awarded via an annual Kremlin-sponsored grant competition since 2006 (Richter 2009:8). These grants have largely focused on funding projects relating to health; youth; civil society development; socially disadvantaged groups; education; and culture (Henderson 2011). Although in 2010 human rights NGOs were added to the list of organisations eligible to receive government grants, the focus has very much been on assisting socially oriented NGOs [SO NGOs] (Kononova 2010). Richter (2009:8) argues that 
this funding drive is part of the Kremlin's policy of making Russian civil society a 'coherent, ordered space where individuals assist the state in the interest of the whole.' This policy has been replicated at a regional level for NGOs providing certain essential social services and has largely (although not exclusively) replaced funds provided by Western donors who until 2005 were the main sources of financing for Russia's civil society organisations (Tarasenko in this volume; McIntosh Sundstrom and Beznosova 2009). In addition, federal legislation in 2010 introduced tax breaks and other more favourable working conditions for NGOs which act as service providers in the social sphere (see Tarasenko in this volume; Chebankova 2013). Various scholars now see civil society as being almost completely subordinated to the state, with Ljubownikow et al (2013:155) arguing that this 'Russian-style' civil society, or civil society po-russki, gives the state 'a dominant, directing and all-encompassing role with regard to civil society formation and development.' This article, however, seeks to challenge the assumption that SO NGOs in Russia have become mere 'marionette' organisations incapable of influencing government social policy (Crotty et al 2014) or of advocating for the social rights and entitlements of their constituents.

\section{$\underline{\text { Welfare and social rights under Putin }}$}

When considering the role of SO NGOs in Russia, due attention must be given to the major changes which the Russian welfare system has undergone under Putin and the changing rhetoric on social rights and state obligations which have accompanied them. The state's perceived role in relation to welfare provision and the protection and promotion of social rights such as the right to housing, healthcare and social security has long been an area of considerable debate, particularly during periods of economic recession such as that which began in 2008. The idea that the state must at some level provide financial and political resources if these rights are to be upheld tends to be fairly widely accepted (Eide and Rosas 2001; van Boven 1982). However, the degree to which the state must provide these resources and the question of whether social rights do in fact constitute human rights or may in fact simply be some form of civic right or claim remains contested (Cranston 1983; Wellman 1982).

In Russia, however, social rights have long been both uncontested and accorded considerable official status. The Soviet Constitution of 1936, for example, guaranteed a large number of economic and social rights for its citizens including the right to employment, leisure, and 
material security in old age and illness, although many of these provisions were only guaranteed for those classified as 'workers' (Nathans 2011:171). The priority given to this particular group of rights is also evident in the Soviet Constitution of 1977. This outlined the right to work, rest and leisure, health protection, care in old age, sickness or disability, housing and education while placing certain limits on civil and political rights (Hawkesworth 1980; Dean 1980). It is worth noting that, despite this rhetorical commitment to guaranteeing such rights, in practice various social services were indeed delivered by the Soviet state but, as Sajo (1996: 141) points out, the state '...provided its services on a discretionary basis and in exchange for loyalty in everyday life.'

Nevertheless, the fact that social rights were so clearly outlined and promoted on an official level indicates that a clear understanding of 'human rights' existed in the Soviet Union, and that there was an extensive culture of rights which emphasised the social and economic over the civil and the political. Following the collapse of the Soviet system, the Russian Constitution of 1993 remedied earlier constraints on civil and political rights and freedoms but continued to commit the Russian Federation to being a 'social state.' Within this state 'the labour and health of people shall be protected, a guaranteed minimum wages and salaries shall be established, state support ensured to the family, maternity, paternity and childhood, to disabled persons and elderly people, the system of social services developed, state pensions, allowances and other social security guarantees shall be established.' ${ }^{2}$ The extent to which this commitment has been reflected in both policy terms and official rhetoric has fluctuated considerably during Putin's tenure. Putin's first term from 2000-2004 was characterised by market-driven reforms introducing liberalization and privatisation to Russia's crumbling but still-extensive state welfare system which it had inherited from the Soviet era (Cook 2007a). From 2005, however, a new strategy of recentralization and increased rhetoric emphasising the role of the state in providing social services was in evidence (Cook 2011), with a series of 'national projects' launched by the authorities to improve standards in healthcare, housing, education and agriculture, as discussed below.

One issue which may have influenced this shift in policy is that, despite major changes in the formal role of the state in providing welfare services since the collapse of the Soviet Union in

\footnotetext{
2 See Article 7, Chapter 2 of the Constitution of the Russian Federation, 'Konstitutsiya Rossiiskoi Federatsii,' available at http://constitution.garant.ru/ [accessed 11th November 2013]
} 
1991, the wider Russian public largely continues to see the state as the first port of call for solving social problems. Domrin (2003:201), for example, argues that ' ...in the Russian interpretation...the state is responsible for maintaining social justice and approximately equal levels of material wealth for its citizens.' This appears to be supported by polling data from 2010 , which indicates that $77 \%$ of those surveyed thought that 'the state should care more about its people,' while only $12 \%$ believed that 'people should act on their own initiative and take care of themselves' (Levada Center 2011). In January 2005 the government attempted to reduce the state's obligations in the social sphere by replacing various 'in-kind' social subsidies for housing, healthcare and transport dating from the Soviet era and paid to groups such as pensioners and disabled people with lower-value cash payments. This led to the largest public demonstrations against the government in a decade (Buckley and Ostrovsky 2005; Wengle and Rasell 2008). Tarasenko and Kulmala (2014) take this further by arguing that the protests led to the reform being implemented only to a very limited extent and in a manner which differed widely from region to region. This indicates that, contrary to the widely-held view of a rigid and unbending regime, the Russian system can in certain circumstances be receptive to popular claims made upon it.

Evidence of the impact of such popular demands on official policy can be seen in the fact that from 2005 onwards, Putin's presidential administration started to move away from a more explicitly market-based welfare policy and tried to portray itself as a champion of social rights issues. Its most prominent policy tool was the launch of a series of "national priority projects' aimed at raising standards in four key policy areas: healthcare, housing, education and agriculture. ${ }^{3}$ Since Putin's re-election as president in February 2012 his approach of flagging up his intentions to uphold social rights in order to appease public protests has become prominent. This was demonstrated by an article written in response to large-scale political demonstrations across Russia in late 2011 and early 2012 protesting against electoral fraud committed during the country's parliamentary elections in December 2011. While stating his commitment to 'genuine democracy,' Putin also claimed:

In terms of which rights people consider to be their priorities, the right to employment (and with it the right to earn an income), the right to free healthcare and education for

3 'Kak rozhdalis' ideya natsionalnikh proektov?,' Presidential Council on Implementing National Priority Projects and Demographic Policy, 16 March 2006, available at http://www.rost.ru/main/what/01/01.shtml [accessed 2nd August 2013] 
children are a long way ahead at the top of the list. Restoring and guaranteeing people these rights has been the key objective of the Russian state. ${ }^{4}$

The Russian economist Yevgeniy Gontmakher has described this co-optation of social rights as Putin's 'new social contract' with the population in exchange for 'society's political indifference.' ${ }^{5}$ The extent to which this 'social contract' can continue to hold, however, is as yet unclear given the recent downturn in economic output and the increasing likelihood of unpopular budget cuts (Bloomberg2014; Stanovaya 2014). ${ }^{6}$ Nevertheless, it represents a significant shift in the rhetoric on the state's role in guaranteeing social rights and welfare provision. Indeed, Henry (2009: 52) argues that this 'can be seen as representative of a new discourse on the nature of the state's responsibilities to the public and, by implication, the source of state legitimacy.' This is important because this emphasis on the legitimacy and importance of social rights and the state's role in upholding them by extension legitimises social rights claims on the state by individuals such as those who took part in the 2005 welfare protests or groups such as the NGOs involved in this study. At the same time, the fact that efforts to 'outsource' social services to SO NGOs have increased on both a rhetorical and practical policy level in recent years serves to undermine this emphasis on the state's role in upholding social rights and delivering welfare provision, as shall be further discussed below. It is also important to keep sight of the gap which exists between official rhetoric on social policy and social rights entitlements, and the actual policies being pursued. Indeed, the rhetoric reasserting the role of the state in the lives of its citizens and the importance of certain social rights claims is in fact contradicted by two important factors.

The first of these is that, despite measures such as the National Priority Projects which appear to bring back a 'statist' approach to social welfare, the liberalising welfare reforms of Putin's first term as president from 2000 to 2005 have not been undone. This has left Russia with a mixed system of welfare provision encompassing a public/private mix of healthcare services, a residual system of unemployment protection, a basic safety net of social assistance for the

\footnotetext{
${ }^{4}$ Vladimir Putin, 'Democracy and the quality of government,' Government of the Russian Federation, 6 February 2012, available at http://www.premier.gov.ru/eng/events/news/18006/ [accessed 1st September 2013]

${ }^{5}$ Interview with Yevgeniy Gontmakher by Yevgeniy Yershov, 'Doktrina Putina-1,' Polit.ru, 22 October 2012, available at http://www.polit.ru/article/2012/10/22/gontmakher/ [accessed 5th September 2013]
} 
poorest in society and private markets in education and housing (Cerami 2008). Henry (2009:52) points out that during the second Putin administration of 2004 to 2008 and subsequent Medvedev administration of 2008 to 2012 efforts were made to continue the partial dismantling and further liberalization of the state welfare system. Yet members of both these administrations deliberately '... raised public expectations about the welfare system. They repeatedly have proclaimed the state's technocratic competence in and responsibility for improving the quality and delivery of social services in order to solve problems such as Russia's demographic crisis.'

The second factor is that even those policies which appear to explicitly re-position the state as the provider of certain social benefits may have an agenda which also conforms to a broadly or partially neoliberal approach while also including elements of statist and Soviet-influenced paternalism. This approach allows the state to make the individual responsible for securing his or her own social rights and transfers the provision of formerly -state-run social services to third-sector organisations such as NGOs or to commercial entities (Salmenniemi 2010; see also Tarasenko in this volume). One example of this is the materinskiy kapital, or maternity capital, payment introduced in late 2006 which is awarded to women who have had their second or subsequent child since 1st January 2007. Part of an attempt to tackle Russia's demographic crisis, this policy is highly selective and, as Rivkin-Fish (2010:717) points out, 'largely circumscribed by pro-natalist assumptions about women and the nature of the 'family.' As a result, Hemment (2009:36) argues that such policies do not constitute a rejection of the earlier liberalising reforms. Instead, they form part of a policy of 'Sovietstyle neoliberalism' whereby social welfare issues and 'socialist-sounding claims' are emphasised in official rhetoric but not matched by actual policies aimed at improving welfare provision. This approach of selecting elements of neoliberal and more socialist political discourse and policy and combining them in a curious hybrid is indicative of the Putin regime's broader strategy of attempting to be all things to all people, a strategy which Matza (2009:495) argues combines a mixture of ‘...individualist, patriotic, liberal, neoliberal, and socialist discourses of the self.'

The research study

The findings presented in this article were generated during fieldwork in Russia between 2011 and 2015. A total of 31 in-depth, semi-structured interviews were conducted in the 
cities of Moscow, St Petersburg, Ryazan and Nizhniy Novgorod in 2011, 2014 and 2015 with representatives of 20 local non-governmental organisations (NGOs); 4 regional human rights ombudsmen and their staff $^{7} ; 5$ local academics; and a consultant on social policy. ${ }^{8}$ The NGOs involved in the study fell into two groups: 14 of these NGOs were active in the social sector and work with vulnerable groups such as disabled people, elderly people and children living in state-run institutions such as orphanages. Of these 14 , seven were based in St Petersburg and seven in Moscow. A further six NGOs (four based in St Petersburg and one each in Ryazan and Nizhniy Novgorod) were organisations which defined themselves explicitly as engaging in human rights or 'rights-defense' activities [pravozashita]. The Ryazan group, however, had at the time of interview recently begun working on a project relating to the social rights of vulnerable groups within the state care-home system (see below). Where the social sector NGOs were concerned, most of these groups conformed to Cook and Vinogradova's (2006) typology of 'Grass-roots II' NGOs concerned with the needs of a specific population category or social problem which have formal structures, professional staff and a corps of volunteers, although two of the Moscow-based organisations had been set up and were being run by full-time but unpaid staff. Almost all of them had extensive experience of working with their local authorities and some had also had contact with federal-level officials. In terms of funding, they relied to varying degrees on municipaland federal-level state funding and direct and in-kind donations from local businesses and individuals, although some also ran small specific projects in cooperation with international NGOs and/or with foreign governmental aid agencies.

While also falling within the 'Grass-roots II' category of NGOs involved in policy formulation and/or advocacy, the human rights NGOs involved in this study differed in several respects from the social sector NGOs mentioned above. These NGOs were all wellknown within the Russian and international human rights community and had extensive

\footnotetext{
${ }^{7}$ At present 63 of Russia's 87 regions have a local human rights ombudsman ('Stanovlenoye instituta Upolnomochenniye po pravam chekoveka,' Official site of the Human Rights Ombudsman in the Russian Federation, available at http://ombudsmanrf.org/2009-11-02-08-43-32/2009-11-19-08-09-17.html). Candidates for the post of regional human rights ombudsmen are approved by the region's local legislature (Roudik 2007). Similarly to the federal-level ombudsmen, the regional ombudsmen are expected to deal with individual and collective complaints concerning rights violations by the local authorities, monitor the human rights situation in their region and cooperate with local bodies such as the prosecutor's office and the courts (Gradskova 2012)

${ }^{8}$ See appendix for a full list of interviews conducted.
} 
experience of receiving grants from foreign foundations and NGOs but received little or no funding from domestic sources. Most of these groups had been established originally by former Soviet dissidents in the late 1980s/early 1990s as informal groups but had developed over time into professionalized organizations advocating policy change and employing several staff and renting office space. All of the NGOs involved in the study were identified initially by their websites and then contacted either directly or through existing contacts.

All the interviews were conducted in Russian by the author and transcribed in full by native speakers before being analysed. All respondents were assured of their anonymity from the initial approach onwards and no names of individual respondents or their organisations were used in the audio recordings in order to ensure anonymity during the transcription process. Given the fact that the interviews with NGOs only involved two select groups of specific NGOs rather than a broader cross-section of groups from across the Russian civil society spectrum, the limitations of the study must be acknowledged. Nevertheless, the findings reported provide a snapshot of the experiences reported by well-established and relatively well-resourced NGOs working in two important spheres of civil society activity in Russia (social policy and human rights). They are also supported by the interviews conducted with additional respondents (the human rights ombudsmen and their staff and local academics) and highlight a number of areas which would be fruitful for further research.

\section{$\underline{\text { Discussion }}$}

Having provided an overview of the various changes and inconsistencies in Russian civil society development and welfare policy during the post-Soviet period, the article now discusses how respondents involved in this study understood the expectations of the state that the wider public may have in relation to social rights and services. It then explores how the SO NGOs who took part in this study seek to manage the political and policy context in which they must operate in order to represent the interests of the groups they work with. The idea that the Soviet legacy of emphasising social rights mentioned above continues to exert a major influence on public expectations of the state's role is one that was raised by several of the respondents interviewed for this study, regardless of the type of organisation they represented: 
A lot of people who lived through the Soviet period expect something similar from the state, because at that time you were guaranteed certain things and it was clearly set out how you could get them. (Valentina, manager of a charity working with elderly people, Moscow $)^{9}$

There are differences between how social rights are understood in Europe and in Russia because of the influence of our Soviet past. Lots of people expect something from the state in the social sphere, whether it's housing or some kind of social security payment. (Katya, staff member for a regional human rights ombudsman, St Petersburg) ${ }^{10}$

While recognising these high public expectations of the Russian state in relation to social rights and various types of social service provision, at the same time these respondents had few illusions about the state's ability, or the government's genuine commitment, to meet these expectations. Several respondents claimed that the government's recent emphasis on social rights was nothing more than a rhetorical ploy designed to win votes:

The government understands that this game with social rights, giving the impression that Russia is a social state, is all just a kind of populist stunt. (Pavel, academic, St Petersburg) $)^{11}$

Our government likes to say that we have a strong state which can provide people with social assistance but we see that those clients who we try to refer to state social services for help end up coming back to us - for the government it's all just words but in reality they do very little. (Lydia, healthcare NGO, Moscow) ${ }^{12}$

Others criticised the public's 'unrealistic expectations' in the social sphere ${ }^{13}$ and pointed out that 'social rights are being violated throughout the country - we are reducing social guarantees in all spheres. ${ }^{14}$ Some respondents gave a more nuanced view of the idea that the

\footnotetext{
${ }^{9}$ Interview, 24 $4^{\text {th }}$ February 2015

${ }^{10}$ Interview, $19^{\text {th }}$ August 2014

${ }^{11}$ Interview, 20 2 th May 2011

12 Interview, $5^{\text {th }}$ April 2011

${ }^{13}$ Interview with Katya, staff member for a regional human rights ombudsman, St Petersburg, $19^{\text {th }}$ August 2014

${ }^{14}$ Interview with Nadya, human rights activist, St Petersburg, 25 $5^{\text {th }}$ April 2011
} 
public held high expectations of the state's obligations in the social sphere, pointing out that while on an abstract level these expectations remained high, in practice most people had long since learned to adapt to Russia's changing system of welfare provision and its frequent failure to deliver on its stated commitments:

The government is increasingly trying to hand over various functions to the commercial sector and reduce its obligations on the quiet. A lot of people have adapted to this and no longer expect much or anything from the state (Valentina, manager of a charity working with elderly people, Moscow). ${ }^{15}$

It is clear that the socially-oriented NGOs involved in this study recognised the limitations caused by both these high expectations and the political framework surrounding them. Where actual policy implications are concerned, however, several of these organisations were keen to highlight their frequent and close contact with municipal, regional and sometimes federal authorities and their input into policymaking. One respondent was clear about the impact she felt her organisation had on government policy at both the regional and federal level:

Virtually all government departments have an advisory board which includes representatives of different social sector NGOs. I am on the board for the transport department so any transport issue which might have implications for disabled people cannot be decided without the opinion of social sector NGOs. This cooperation between social organisations and the authorities is well-established and can only continue to improve - our organisation has plenty of influence. (Alla, disability NGO, Moscow) ${ }^{16}$

Other respondents supported this view that contacts between NGOs and the authorities at the local level in particular were regular and fruitful:

These advisory boards bring together bureaucrats and government representatives all the time in order to tell them what the NGOs and the public think are the main issues that need to be resolved. And this does lead to some progress (Anna, disability NGO, Moscow). ${ }^{17}$

\footnotetext{
${ }^{15}$ Interview, 24 ${ }^{\text {th }}$ February 2015

${ }^{16}$ Interview, 26 ${ }^{\text {th }}$ February 2015

${ }^{17}$ Interview, 30 $0^{\text {th }}$ April 2015
} 
We cooperate the whole time with the [municipal] Committee for Social Policy, the Health Committee, the Prosecutor's Office, the human rights ombudsmen at the regional and federal level and so on. There are formal and informal meetings, communication etc going on all the time so we're always in contact with them. (Aleksandr, programme officer for a homeless charity, St Petersburg) ${ }^{18}$

This view was one shared by other respondents involved in this study and reflects the pragmatic stance taken by many social sector NGOs who seek to 'get things done', ${ }^{19}$ whereby the process by which change or reform happens appears to be less important than the final, practical outcome. While the true intentions of the government's rhetoric may be unclear, based on some of the interviews conducted with this type of NGO it seems that it may to some extent be influencing policy development. Indeed, one organisation pointed to the issue of inclusive education which it had campaigned on for a number of years and which finally came to fruition in late 2012 when a federal law was passed which guaranteed the right of children with disabilities to be educated in mainstream schools rather than in specialised facilities alone (RIA Novosti 2013). On a more regional level, SO NGOs also point to their long-standing cooperation with local authorities and with the federal-level Ministry for Economic Development [Ministerstvo ekonomicheskovo razvitiya]: a report issued by the ministry in 2013, for example, includes testimony from a representative of an NGO working with children with Down's Syndrome who comments on the 'effective cooperation' her organisation enjoys with Moscow's regional departments for Health, Education and Social Protection:

At present we can say with confidence that there is an effective model of partnership between the government and NGOs in Moscow for establishing an educational route for each child with Down's syndrome from birth until school age, based on an individual approach and access to educational services at the family's place of residence (Rigina 2013:166).

In addition to regular meetings with various government representatives, in terms of funding almost all of the socially-oriented NGOs involved in the study had at various points received

\footnotetext{
18 Interview, $16^{\text {th }}$ April 2015

${ }^{19}$ Interview with Maria, disability NGO manager, St Petersburg, 11 ${ }^{\text {th }}$ March 2011; Interview with Lydia, healthcare NGO manager, Moscow, $5^{\text {th }}$ April 2011
} 
federal or regional funding for their programmes in the form of direct grants or subsidies such as reduced rent for their organisation's premises. Those that had not yet received such funding intended to apply for the necessary schemes in the near future. The amount of funding varied from as little as $10 \%$ of one organisation's total income to $90 \%$ for one programme run by a disability $\mathrm{NGO}$, and several respondents were again positive about the impact of this funding:

We receive a lot of money from the National Charity Fund and the National Foundation for Support of Children in Difficult Life Situations. One of these has close ties to the president, the other is linked to the prime minister. We regularly receive grants from these foundations and in many respects they really help us to do what we do. (Svetlana, fostercare charity, St Petersburg) $)^{20}$

There are subsidies which we receive from the [municipal] Committee for Social Policy and then there are the federal subsidies which we also receive. We are well-known and respected in the city so generally we write project proposals and we almost always receive funding for them (Natasha, manager of a charity working with elderly people, St Petersburg $)^{21}$

The apparent closeness and regularity of the contacts between SO NGOs and local/federal authorities in both personal and financial terms seems in some respects to support the notion that this type of organisation is at risk of being 'co-opted' by the state into its plans to regulate and control civil society in Russia. Yet several of the respondents interviewed for this study noted that where the field of welfare provision and social work is concerned, the situation may not be that simple. On the one hand, given the scarcity of resources available for NGO activity in Russia, many groups engaged in socially-oriented work have little choice but to accept funding from local or federal government sources. As Javeline and LindemannKomarova (2010:179) point out, 'the alternative of completely avoiding funding by Russian local or federal government is not in the interests of civil society development, especially if the low level of resources otherwise available to most Russian citizens would prevent them from organizing.' Other respondents pointed to the necessity of such collaboration for social

\footnotetext{
${ }^{20}$ Interview, 28 ${ }^{\text {th }}$ February 2011

${ }^{21}$ Interview, 24 ${ }^{\text {th }}$ April 2015
} 
sector NGOs if they wantED to realise their aims, and compared this approach with what they saw as the more confrontational stance taken by some Russian human rights NGOs. Several argued that these 'old-style' groups had a very different understanding of 'what rights are, how to create and facilitate change, and how to have a normal, constructive discussion with the government' (Nadezhda, children's charity manager, St Petersburg): ${ }^{22}$

Those [human rights NGOs] take a very categorical, oppositional stance. Because we have a lot of projects that are connected to social services...we have to maintain a more restrained position and try to cooperate with the authorities, find compromises and engage in dialogue. (Lydia, healthcare charity, Moscow) ${ }^{23}$

Due to the fact that our organisation works in the social sphere, unlike the human rights activists I can't just ignore the authorities, I have to work with them and ask them for help.

\section{(Maria, disability NGO, St Petersburg) ${ }^{24}$}

While acknowledging, however, the necessity of cooperation with the authorities and of applying for and receiving funding from state sources, many of the NGOs interviewed for this study remained extremely critical of the approach taken by the government towards so NGOs and social service delivery. They also continued to develop a diverse range of alternative sources of financial and other support including 'social enterprise' activities such as festivals and concerts, cash and in-kind donations from local businesses and individuals, volunteering, and, in some cases, financial support from foreign foundations and organisations. Several, however, expressed concern over the impact the 'foreign agent' law might have on their ability to do this in the future and the impact it was already having on other organisations in the field, ${ }^{25}$ with one pointing out that foreign funding had already begun to decline even before the law was introduced in 2012 as many international

\footnotetext{
22 Interview, 22 ${ }^{\text {nd }}$ February 2011

${ }^{23}$ Interview, 5th April 2011

${ }^{24}$ Interview, $11^{\text {th }}$ March 2011

25 Interview with Masha, manager, disability NGO, St Petersburg: 16th April 2015; and Aleksandr, programme officer, homeless charity, St Petersburg: 17th April 2015
} 
foundations closed down their branches in Russia. ${ }^{26}$ This criticism of the authorities and eagerness to avoid total financial dependence on them is particularly interesting given that efforts by the authorities to involve this type of organisation in the direct provision of social services have intensified since 2011. This has been coordinated in large part by the Ministry of Economic Development and has taken the form of both more accommodating national and regional legislation governing the activity of SO NGOs and substantial federal and regional grant competitions. As of 2014, federal and municipal commissioners of social services must award no less than $15 \%$ of procurement to socially-oriented NGOs and/or commercial enterprises (Tarasenko 2013). This increased emphasis has also been reflected at the official level, with President Putin stating in late 2014 that,

We will continue to support socially-oriented non-commercial organisations. As a rule these organisations bring together people with a keen sense of civic duty who understand the meaning of charity, care and kindness. We must use their ideas and experience to implement social initiatives. (Putin 2014)

One respondent hailed this change in the legislative environment for SO NGOs as a "positive moment' which would hopefully allow such NGOs to 'provide high-quality social services across the territory of the Russian Federation. ${ }^{, 27}$ Many of the organisations involved in this study were also enthusiastic about the idea of NGOs such as theirs being involved in service provision since they argued that their organisations could be 'a real help to the state as we can deliver innovative social services effectively and for not much money' ${ }^{28}$ and are 'focused on delivering results for our clients. ${ }^{29}$ When it came to the practical implementation of this policy, however, nearly all the organisations interviewed were fiercely critical of bureaucratic issues such as the sheer volume of paperwork required for NGOs wishing to apply for direct grants and/or tenders to deliver social services, and of the continuing need for personal connections in order to be successful in gaining official funding. In addition, a number of those interviewed expressed grave reservations about the motivations behind the policy and the implications it might have on the ability of NGOs such as theirs to operate independently.

\footnotetext{
26 Ibid

${ }^{27}$ Interview with Yana, fostercare charity manager, St Petersburg, 28 $8^{\text {th }}$ February 2011

${ }^{28}$ Interview with Natasha, manager of a charity working with elderly people, St Petersburg: 24th April 2015

${ }^{29}$ Interview with Masha, manager, disability NGO, St Petersburg: 16th April 2015
} 
Some, for example, felt that the policy was an attempt to save money which emphasised the cost of service delivery over its quality and ability to meet clients' needs, ${ }^{30}$ or that it might just be a passing fad with 'SO NGOs being supported today but tomorrow the money could go to someone else.' ${ }^{31}$ Others pointed out that the government's attempts to transfer elements of social service provision to these NGOs could be an attempt to control those organisations which become official service providers 'either in full or in part. ${ }^{32}$ One respondent highlighted what she saw as the contradictory impulses at play within the policy, whereby:

The government is trying to use SO NGOs to make up for the deficiencies in the system, they are hoping that NGOs will deliver the same services for less money. But at the same time it wants to control the process - so it's incapable of allowing NGOs the freedom they need to develop new ideas and methods which might be beneficial. (Anastasiya, manager of a healthcare charity, Moscow) ${ }^{33}$

Indeed, this idea of the 'freedom' enjoyed by SO NGOs who currently offer social services on a relatively small and localised scale was one protected fiercely by several interviewees, who cited their fear of losing their ability to operate independently as one of the main reasons why they were, at least at present, not interested in becoming formal government-funded service providers:

At the moment we are free, we can create models which really benefit our clients. If this was all more strictly regulated then either we would have to lie and say that we have done the kind of box-ticking they want or we would have to change our principles and turn into some kind of state bureaucratic structure which we don't want to do (Masha, manager, disability NGO, St Petersburg) ${ }^{34}$

It's unlikely we'll apply for one of these social service tenders because we don't want to provide services the way the authorities currently do, we don't like how they are

\footnotetext{
${ }^{30}$ Inter views with Natasha, manager of a charity working with elderly people, St Petersburg: 24th April 2015; and Masha, manager, disability NGO, St Petersburg: 16th April 2015

31 Interview with Natasha, manager of a charity working with elderly people, St Petersburg: 24th April 2015

32 Interview with Aleksandr, programme officer, homeless charity, St Petersburg: 17th April 2015

${ }^{33}$ Interview, $19^{\text {th }}$ February 2015

${ }^{34}$ Interview, 16th April 2015
} 
organised. And of course organisations which do want to work in that way would have to change their activities drastically. (Aleksandr, programme officer, homeless charity, St Petersburg $)^{35}$

Overall, the data indicates that, where social rights issues related to state provision of social services are concerned, some NGOs recognise the necessity of cooperating with state structures to whatever degree they reasonably can since ultimately such problems can only be resolved by the state. The application of a 'statist' model to relations with civil society is often seen in a negative light since it appears to imply the cooptation of civil society by the state and the subsequent diminishing of independence for civil society groups, with those deemed 'undesirable' or unhelpful in terms of realising the state's goals ostracised or punished. McIntosh Sundstrom and Beznosova (2009), for example, argue that, unlike grants supplied by Western donors, state funding to civil society organisations is an attempt to control their political agendas. According to Kononova (2010), Russian and international human rights groups see state support and state control as 'different sides of the same coin.'

Yet it is not clear that any state involvement in funding or collaborating with civil society organisations must automatically be a dangerous move which compromises an NGO's independence or forces it to adopt political objectives which it would not otherwise have done. Indeed, the findings from this study indicate that, as mentioned above, several of the Russian civil society representatives who took part in this study saw cooperation with the local authorities in particular as unavoidable in terms of their ability to achieve their aims and assist those on whose behalf they operate. They were, in fact, in several cases cautiously optimistic about the results such cooperation could produce. Indeed, Kulmala (2011:74) points to the mutually beneficial relationship established between local authorities and civil society organisations that she identified during her fieldwork in the Russian region of Karelia. She points out that '...cooperation does not necessarily mean co-optation...civil society organisations have the most influence in situations when they collaborate actively with the local authorities and... when the roles of the state and civil society actors overlap.' Certainly such cooperation offers at least the possibility of input into policymaking where social policy and the realisation of certain social rights are concerned, whereas human rights NGOs have

${ }^{35}$ Interview, $17^{\text {th }}$ April 2015 
for the most part been shut out of the policymaking process during Putin's tenure (Klitsounova 2008).

As the respondents in this study noted, cooperation with the authorities is both a fact of life for socially-oriented NGOs and a potential means for them to influence policy development and practice in the social sector. Those involved in foster care and other social work relating to children were particularly positive about their interactions with local and federal authorities. In addition, even if the state's support for a particular organisation does lead it to adopt certain aims or objectives in order to ensure that this support continues, this is surely no different from the effects of funding which comes from Western donors. Henderson (2002: 142) points out that, prior to the Kremlin's policy of providing funding to certain segments of civil society, Russian NGOs tailored their projects to meet what they believed to be the interests of potential Western donors rather than the Russian population since these donors were 'the voice that mattered.' As a result, it seems to be something of a double standard to assume that Western financial support for NGOs is always benign and apolitical whereas grants from the Russian state must automatically have some sinister intent. It therefore seems possible that the emphasis on the statist conceptualisation of state-civil society relations as the model that best represents current interactions between the Russian state and NGOs, and on the presumed negative consequences of this model, has been overstated. Kulmala (2011:55), for example, argues for the application of a 'Nordic' model to the Russian case since the norm in Nordic countries is for civil society organisations to receive full or partial state subsidies. In this case, 'close collaboration between state authorities and civil society without destroying the autonomy of civil society is achievable.' In addition, it appears that many SO NGOs engaged in this kind of collaboration with state structures have a clearsighted and pragmatic view of the merits and risks of this type of cooperation and remain protective of their ability to operate independently while taking advantage as best they can of the financial assistance offered to them by the federal and regional authorities. Their wariness of the government's attempts to involve them more deeply in the formal provision of social services has implications for the implementation of this policy since it gives them a degree of agency. The state is keen to take advantage of their expertise and experience in the field but they are not obliged to agree to this and the existence of alternative funding sources and local community support for their work allows them to operate with a certain degree of freedom. 
It is also worth noting that where issues connected to social rights and social problems are concerned, regional state structures such as the governor's office and the regional and municipal parliaments and local authorities are often more important than the federal government (see also Tarasenko in this volume). While some of the social sector NGOs operating in St Petersburg were cautiously positive about their relations with the city and oblast [regional] authorities, in the case of Ryazan the situation was more complex. The Ryazan-based NGO involved in this study had traditionally focused much more on civil and political rights issues and had close ties to some of the larger and more longstanding human rights NGOs based in Moscow. Recently, however, it had initiated a programme asserting the rights of children leaving the care system in Ryazan Oblast [the federal subject which includes the city of Ryazan] to housing which the local authorities are legally obliged to provide. While the NGO's employees had been pleasantly surprised by the 'hugely successful' response this campaign had received from the local population, they maintained that their actions had antagonised the region's governor. He then set out to discredit their organisation and limit public access to information about their campaign:

The governor ordered the local media not to publish any information provided by us, so effectively information from us and our organisation was censored. (Dmitriy, human rights activist, Ryazan $)^{36}$

Then the local government press service said that we'd lost our minds and were demanding that they take apartments away from people who already had them, that we had just totally lost it. (Tanya, human rights activist, Ryazan) ${ }^{37}$

This indicates firstly that the apparent emphasis at the level of federal government on upholding social rights has not necessarily filtered down unadulterated to the individual regions. This picture of regional diversity is confirmed by a report compiled in 2010 by the Council of Europe, which runs a joint EU-Council of Europe programme on national human rights structures which in the Russian case includes the regional human rights ombudsmen. According to the report, which concerned the role of the human rights ombudsman in the defence of social rights during economic crisis,

\footnotetext{
${ }^{36}$ Interview, $13^{\text {th }}$ June 2011

${ }^{37}$ Interview, $13^{\text {th }}$ June 2011
} 
The current reality in Russia, as concerns the respect of social and economic rights, is characterised by a very diverse national legislation, the absence of a common benchmark and the different approach by each region according to budget availability. Thus, the respect for the rights of socially vulnerable people greatly varies in the Russian Federation. (Valenti 2010).

It also indicates that, even where an NGO takes up an economic or social rights issue which is clearly of importance to the local population and is in line with what Putin apparently sees as a 'legitimate' rights claim, its efforts can potentially be stymied by opposition from regional power-brokers. This therefore makes it difficult to talk of any uniform approach towards social rights and social service provision on the part of 'the state' in Russia since there is a plurality of relevant state structures on both a federal and regional level which may have quite different objectives. This picture of regional diversity was one raised by a number of other NGOs who pointed to the substantial differences that exist between the major cities of Moscow and St Petersburg and the rest of the country: many claimed that 'things are done differently in the regions, it's much freer in Moscow and St Petersburg' ${ }^{38}$ and that 'there's less funding in the regions and a lot of different problems there so it's harder for NGOs to work there and have dialogue with the authorities. ${ }^{39}$ Nevertheless, in the case of Ryazan activists remained positive about the outcomes of their campaign. They pointed out that ultimately a large amount of municipal funding had been set aside to deal with housing for children leaving the local care system and that 'on a regional level there is now some recognition of the problems that orphans face. ${ }^{40}$ In addition, other NGO representatives recognised that where Moscow and St Petersburg led, other regions tended to follow and highlighted their strong connections and frequent contacts with NGOs working on similar issues across the country. ${ }^{41}$ As a result, it seems clear that a more micro-level focus on regional approaches and developments in terms of the interaction between socially-oriented

\footnotetext{
${ }^{38}$ Interview with Natasha, manager of a charity working with elderly people, St Petersburg: 24th April 2015

${ }^{39}$ Interview with Alina, Vera and Alla, programme officers for a disability charity, Moscow: 26th February 2015

${ }^{40}$ Interview, $11^{\text {th }}$ June 2011

${ }^{41}$ Interview with Nadezhda, children's charity manager, St Petersburg: 22nd February 2011; Alina, Vera and Alla, programme officers for a disability charity, Moscow: 26th February 2015; Natasha, manager of a charity working with elderly people, St Petersburg: 24th April 2015
} 
NGOs and the authorities has more to reveal than focusing simply on federal-level policies and legislation in this area.

\section{Conclusions}

This article has sought to provide some insight into the ways in which various Russian civil society actors conceptualise the role of the state in guaranteeing social rights. It has argued that the Soviet policy of emphasizing social and economic rights over civil and political human rights continues to provide the context for current understandings of the state and shapes public expectations of what the state can and should provide in relation to welfare. In addition, it has explored how these expectations have influenced the policy of the various presidential administrations since 2005. A fairly recent and increasingly prominent aspect of this policy has been to involve socially oriented NGOs in the direct provision of social services which have traditionally fallen within the state's welfare remit. This has taken place even as official rhetoric has sought to portray Russia as having a 'social state' which is anxious to uphold its citizens' social rights. As a result, the Putin and Medvedev administrations have sought to give the impression of reasserting the state's primacy in relation to guaranteeing social rights through social service provision while maintaining what is in fact a mixed model of neoliberal and state-centred welfare policy. Within this complex and rapidly changing political and social context, the article has shed light on how socially oriented NGOs in Russia which seek to mitigate social problems interact with state authorities in order to advocate for the social rights of the populations they seek to assist. The research findings indicate that operating within this complex, hybrid field of welfare provision has in general led social sector NGOs to adopt a pragmatic approach to cooperation and collaboration with local government authorities and other state structures. This appears, with certain caveats, to provide them with the opportunity to influence government policy and practice relating to their work and these opportunities may well increase as and when such organisations take up an increasing role in the delivery of a range of social services.

Naturally the small-scale study on which this article is based has certain limitations in terms of representativeness, and further research on the changing and growing relationship between socially oriented NGOs and the Russian state would be both timely and fruitful. Nevertheless, these findings point to some preliminary implications for the further development trajectory of Russian civil society more generally. It seems clear that the Russian authorities aspire in 
many respects to conform to a 'statist' model of civil society relations whereby civil society is seen as a partner of the state, to be actively shaped and influenced. This has had clear, and undoubtedly negative, implications for those NGOs engaging in human rights and environmental advocacy in particular who have struggled to continue their activities in an increasingly restrictive legislative and wider political environment. Where SO NGOs are concerned, however, this article has argued that the picture is somewhat different. Such organisations have been the target of as much, if not more, attention from the authorities but, given their potential for acting as 'partners' to the state in the delivery of social services, this attention has recently taken a very different, and far more positive, tone. . At the same time, SO NGOs are often highly critical of government action in the social policy arena and are suspicious of attempts to involve them more closely in the direct provision of state social services through grant competitions and tenders for service contracts. This indicates that the government has a great deal more work to do in convincing these organisations of the merits of cooperating with the authorities on a more formal and regulated basis than they currently do.

There is a common and understandable perception that cooperation between SO NGOs and the authorities must lead to the Russian state 'co-opting' organisations which receive government funding in this field and a subsequent and severe loss of agency on their part. However, this is always not borne out by the findings this study has generated which indicate that this type of NGO can in some cases retain a degree of agency and independence with which to advocate for what they perceive to be the needs of their constituents. Overall, the relationship between the Russian state and SO NGOs appears to be more complex, nuanced and mutually constitutive than the antagonism and distrust which tends to characterise analysts' conceptions of the Russian state-civil society relationship, particularly where the authorities' dealings with human rights groups are concerned. A broader and more flexible understanding of what constitutes the field of 'Russian-style' civil society may thus be more relevant in the contemporary context.

\section{Appendix A: List of interviews conducted in Russia}

1. Yulia, human rights activist, St Petersburg: 18th February 2011

2. Nadezhda, children's charity manager, St Petersburg: 22nd February 2011 
3. Svetlana, employee of an NGO promoting foster care, St Petersburg: 28th February $\underline{2011}$

4. Yana, manager of an NGO promoting foster care, St Petersburg: 28th February 2011

5. Maria, manager of an NGO working with elderly people and disabled, St Petersburg: 11th March 2011

6. Sergey, advisor to a regional child human rights ombudsman, St Petersburg: 20th $\underline{\text { March } 2011}$

7. Lyuda, human rights activist, St Petersburg: 22nd March 2011

8. Oleg, human rights activist, St Petersburg: 22nd March 2011

9. Lydia, healthcare NGO manager, Moscow: 5th April 2011

10. Marina, programme officer for an NGO promoting labour/social rights, Moscow: 14th April 2011

11. Andrey, regional human rights ombudsman, Moscow Region: 14th April 2011

12. Nikolai, regional human rights ombudsman, Northwestern Federal District: 16th April $\underline{2011}$

13. Nadya, human rights activist, St Petersburg: 25th April 2011

14. Andrey, academic, St Petersburg: 20th May 2011

15. Pavel, academic, St Petersburg: 20th May 2011

16. Stanislav, academic, St Petersburg: 26th May 2011

17. Dmitriy, human rights activists, Ryazan: 13th June 2011

18. Tanya, human rights activists, Ryazan: 13th June 2011

19. Sergey, human rights activist, Nizhniy Novgorod: 7th June 2011

20. Aleksey, academic, St Petersburg: 18th June 2011

21. Vadim, academic, St Petersburg: 20th June 2011 
22. Katya, staff member for a regional human rights ombudsman, St Petersburg: $19^{\text {th }}$ August 2014

23. Vladimir, consultant on social policy, Moscow: $18^{\text {th }}$ February 2015

24. Anastasiya, manager of a healthcare charity, Moscow: $19^{\text {th }}$ February 2015

25. Valentina, manager of a charity working with elderly people, Moscow: $24^{\text {th }}$ February $\underline{2015}$

26. Alina, Vera and Alla, programme officers for a disability charity, Moscow: $26^{\text {th }}$ February 2015

27. Masha, manager, disability NGO, St Petersburg: $16^{\text {th }}$ April 2015

28. Aleksandr, programme officer, homeless charity, St Petersburg: $17^{\text {th }}$ April 2015

29. Natasha, manager of a charity working with elderly people, St Petersburg: $24^{\text {th }}$ April $\underline{2015}$

30. Anna and Viktoriya, managers of a disability charity, Moscow: $30^{\text {th }}$ April 2015

31. Olga, manager of a healthcare charity, Moscow: $30^{\text {th }}$ April

\section{References}

Abrams, P (1988) 'Notes on the Difficulty of Studying the state (1977),' Journal of Historical Sociology, Vol.1:1, pp.58-89

BBC News (2012) 'Russia: Controversial NGO Bill Becomes Law,' 21 July 2012, available at http://www.bbc.co.uk/news/world-europe-18938165 [accessed 11 November 2013]

Beznosova, O and McIntosh Sundstrom, L (2009) 'Western Aid and the state-Society

Balance in Novgorod and Khabarovsk,' Problems of Post-Communism, 56:6, pp.21-35 
Bloomberg (2014) 'Russian Woes Worsen as Recession Looms with Banks in 'Panic,' BloombergBusiness.com, 2nd December 2014, available at http://www.bloomberg.com/news/2014-12-02/russia-sees-first-recession-since-2009-with-08-slump-next-year.html [accessed 1st March 2015] van Boven, T (1982) 'Distinguishing Criteria of Human Rights' in Vasak, K (ed.) The International Dimensions of Human Rights, US:UNESCO

Buckley, N and Ostrovsky, A (2005) 'Huge protests in Russia over benefits,' Financial Times, 17th January 2005, available at http://www.ft.com/cms/s/0/93dba120-682c-11d9a11e-00000e2511c8.html\#axzz28XEvuByz

Cerami, A (2009) 'Welfare State Developments in the Russian Federation: Oil-Led Social Policy and 'The Russian Miracle',' Social Policy and Administration, Vol.43:2, pp.105-120 Chebankova, E (2013) Civil Society in Putin's Russia, UK: Routledge

Cook, L (2007a) 'Negotiating Welfare in Postcommunist States,' Comparative Politics, 40:1, pp.41-62

Cook, L (2007b) Post-Communist Welfare States: Reform Politics in Russia and Eastern Europe, US: Cornell University Press

Cook, L (2011) 'Russia's Welfare Regime: The Shift Toward Statism' in Jappinen, M, Kulmala, M and Saarinen, A (eds.) Gazing at Welfare, Gender and Agency in Post-socialist Countries, UK: Cambridge Scholars Publishing

Cook, L and Vinogradova, E (2006) 'NGOs and Social Policymaking in Russia's Regions,' Problems of Post-Communism, Vol.53:5, pp28-41

Cranston, M (1983) ‘Are There Any Human Rights?’ Daedalus, Vol.112:4, pp.1-17

Crotty, J (2003) 'Managing civil society: democratisation and the environmental movement in a Russian region,' Communist and Post-Communist Studies, 36, pp.489-508

Crotty J; Hall, S-M and Ljubownikow. S (2014) 'Post-Soviet Civil Society Development in the Russian Federation: The Impact of the NGO Law,' Europe-Asia Studies, Vol.66:8, pp. 1253-1269 
Dean, R (1980b) 'Contacts with the West: The Dissidents' View of Western Support for the Human Rights Movement in the Soviet Union,' Human Rights Quarterly, Vol.2:1, pp47-65

Domrin, A (2003) 'Ten Years Later: Society, 'Civil Society,' and the Russian State,' The Russian Review, 63, pp.193-211

Donnelly, J (1982) 'Human Rights and Human Dignity: An Analytic Critique of NonWestern Conceptions of HR,' The American Political Science Review, Vol.76:2, pp. 303-316 Easter, G (2008) 'The Russian State in the Time of Putin,' Post-Soviet Affairs, Vol.24:3, pp.199-230

Eide, A and Rosas, A (2001) 'Economic, Social and Cultural Rights: A Universal Challenge' in Eide, A and Helgesen, J (eds.) Economic, Social and Cultural Rights: A Textbook, The Hague: Kluwer Law International

European Human Rights Advocacy Centre (2013) 'Winter Bulletin,' No.20, available at http://www.mdx.ac.uk/_data/assets/pdf_file/0005/58658/EHRAC-Winter-Bulletin-2013ENG-WEB.pdf [accessed 28th November 2014]

Evans, A (2006) 'Vladimir Putin's Design for Civil Society' in Evans, A; Henry, L and McIntosh-Sundstrom, L (eds.) Russian Civil Society: A Critical Assessment, London:M.E.Sharpe

Evans, A (2012) 'Protests and civil society in Russia: The struggle for the Khimki Forest,' Communist and Post-Communist Studies, Vol.45, pp.233-242

Frohlich, C (2012) 'Civil society and the state intertwined: the case of disability NGOs in Russia,' East European Politics, Vol.28:4, pp. 371-389

Gradskova, Y (2012) 'Regional Ombudsmen, Human Rights and Women - Gender Aspects of the Social and Legal Transformation in North-West Russia (Based on Ombudsman Reports),' The Soviet and Post-Soviet Review, Vol.39, pp.84-109

Griffin, J (2000) 'Welfare Rights,' The Journal of Ethics, Vol.4, pp.27-43

Hale, H (2002) 'Civil Society from Above? Statist and Liberal Models of State-Building in Russia,' Demokratizatsiya, Vol. 10:3, pp.306-321 
Halliday, F (1987) 'State and Society in International Relations; A Second Agenda,' Millenium, Vol.16, pp.215-229

Hawkesworth, M (1980) 'Ideological Immunity: The Soviet Response to Human Rights Criticism,' Universal Human Rights, Vol.2:1, pp.67-84

Hemment, J (2004) 'The Riddle of the Third Sector: Civil Society, International Aid, and NGOs in Russia,' Anthropological Quarterly, 77:2, pp.215-241

Hemment, J (2009) 'Soviet-Style Neoliberalism? Nashi, Youth Voluntarism, and the Restructuring of Social Welfare in Russia,' Problems of Post-Communism, Vol.56:6, pp.3650

Hemment (2012) 'Nashi, Youth Voluntarism and Potemkin NGOs: Making sense of civil society in post-Soviet Russia,' Slavic Review, Vol.71:2, pp. 234-260

Henderson, S (2002) 'Selling Civil Society: Western Aid and the Nongovernmental Organization Sector in Russia,' Comparative Political Studies, 35:2, pp.139-167

Henderson, S (2011) 'Civil Society in Russia: State-Society Relations in the Post-Yeltsin Era,' Problems of Post-Communism, 58:3, pp.11-27

Henry, L (2009) 'Redefining Citizenship in Russia: Political and Social Rights,' Problems of Post-Communism, 56:6, pp.51-65

Human Rights Watch (2014) 'Russia: Government against Rights Groups,' $20^{\text {th }}$ November 2014, available at http://www.hrw.org/news/2014/11/20/russia-government-against-rightsgroups [accessed 28th November 2014]

Interfax (2013) 'Russians' greatest worry is corruption; only 4 percent worried about rights poll,' 21st March 2013, available at http://russialist.org/russians-greatest-worry-is-corruptiononly-4-percent-worried-about-rights-poll [accessed 11th November 2013]

Javeline, D and Lindemann-Komarova, D (2010) 'A Balanced Assessment of Russian Civil Society,' Journal of International Affairs, Vol.63:2, pp.171-188

Jessop, B (2008) State Power, Cambridge: Polity Press 
Juviler, P (1998) Freedom's Ordeal: The Struggle for Human Rights and Democracy in PostSoviet States, Philadelphia: University of Pennsylvania Press

Klitsounova, E (2008) 'Promoting Human Rights in Russia by Supporting NGOs: How to Improve EU Strategies,' CEPS Working Document No.287/April 2008

Kononova, S (2010) 'Money for the Needy,' Russia Profile, January 2010, available at http://www.russiaprofile.org/politics/a1264450336.html

Konstitutsiya Rossiiskoi Federatsii (1993) available at http://constitution.garant.ru/ [accessed 11th November 2013]

Kulmala, M (2011) 'Russian State and Society in Interaction: An Ethnographic Approach,' Laboraturium Russian Review of Social Research, 1, pp.51-83

Lane, D (1984) 'Human Rights Under State Socialism,' Political Studies, Vol.3:3, pp.349368

Levada Centre (2011) 'Kakoi printsip otnoshenii mezhdu gosurdarstvom i evo grazhdanami vy by lichno podderzhali?', available at http://www.levada.ru/archive/gosudarstvo-iobshchestvo/grazhdane-i-vlast/kakoi-printsip-otnoshenii-mezhdu-gosudarstvom-i- [accessed 10th September 2013]

Levada Center (2011) 'Kakiye iz prav cheloveka, po vashomu mneniyu, naibole vazhni?', 8 September 2011, available at http://www.levada.ru/archive/prava-cheloveka/kakie-iz-pravcheloveka-po-vashemu-mneniyu-naibolee-vazhny-otvety-ranzhirova [accessed 11th November 2013]

Levada Center (2012) 'V. Putin teryaet podderzhku i vliyaniye, vpechatleniye o nyom ykhuzhdayetsya', available at http://www.levada.ru/17-08-2012/vputin-teryaet-podderzhku-ivliyanie-vpechatlenie-o-nem-ukhudshaetsya [accessed 1st November 2013]

Levada Center (2014) 'Martovskie reitingi odobreniya I doveriya,' available at http://www.levada.ru/26-03-2014/martovskie-reitingi-odobreniya-i-doveriya [accessed 30 March 2014]

Levada Center (2014) ('Kakiye iz prav cheloveka, po vashomu mneniyu, naibole vazhni?', Obshestvennoye mneniye/ Levada Center, 2014, available at http://www.levada.ru/books/obshchestvennoe-mnenie-2013 [accessed 1st December 2014]) 
Makarychev, A (2008) 'Politics, the state, and De-Politicization: Putin's Project Reassessed,' Problems of Post-Communism, Vol.55:5. Pp.62-71

Matza, T (2009) 'Moscow's Echo: Technologies of the Self, Publics, and Politics on the Russian Talk Show,' Cultural Anthropology, Vol.24:3, pp.489-522

McIntosh Sundstrom, L (2005) 'Foreign Assistance, International Norms, and NGO Development: Lessons from the Russian Campaign,' International Organization, 59, pp.419449

McIntosh Sundstrom, L and Beznosova, O (2009) 'Western Aid and the state-Society Balance in Novgorod and Khabarovsk,' Problems of Post-Communism, Vol.56:6, pp.21-35 Migdal, J and Schlichte, K (2005) 'Rethinking the state' in Schlichte, K (ed.) The Dynamics of States: The Formation and Crises of State Domination

Mitchell, T (1991) 'The Limits of the state: Beyond Statist Approaches and Their Critics,' American Political Science Review, Vol.85:1, pp.77-96

Mukametshina, E (2015) 'Zayavleniya o vykhode iz reestra inostrannykh agentov podali uzhe 4 NKO,' Vedomosti, available at http://www.vedomosti.ru/newspaper/articles/2015/05/05/zayavleniya-o-vihode-iz-reestrainostrannih-agentov-podali-uzhe-chetire-nekommercheskie-organizatsii [accessed 5th May 2015]

Narozhna, T (2004) 'Civil Society in the Post-Communist Context: Linking Theoretical Concept and Social Transformation,' Demokratizatsiya, Vol.12:2, pp. 294-310

Nathans, B (2011) 'Soviet Rights-Talk in the Post-Stalin Era' in Hoffman, S-L (ed.) Human Rights in the Twentieth Century, Cambridge, UK: Cambridge University Press Mohsin Hashim, S (2005) 'Putin's Etatization project and limits to democratic reforms in Russia,' Communist and Post-Communist Studies, Vol.38, pp.25-48

Official site of the Human Rights Ombudsman in the Russian Federation (2014) 'Stanovlenoye instituta Upolnomochenniye po pravam chekoveka', available at http://ombudsmanrf.org/2009-11-02-08-43-32/2009-11-19-08-09-17.html [accessed 15th September 2013] 
Official Site of the President of Russia (2009) 'Rossiya, vperyod! Stat'ya Dmitriya Medvedeva,' 10 September 2009, available at http://президент.pф/news/5413 [accessed 12th September 2013]

Oversloot (2007) 'Reordering the State (without Changing the Constitution): Russia under Putin's Rule, 2000-2008,' Review of Central and East European Law, Vol.32, pp.41-64

Pensionniy Fond Rossiiskoi Federatsii (2014) 'Informatsiya o materinskom (semyeinom) kapitale', available at http://www.pfrf.ru/family_capital/ [accessed 24 ${ }^{\text {th }}$ June 2014]

Prava cheloveka v Rossii (2012) 'Ombudsmeni obsudyat zlobodneviye temi v sfere zashiti detstva', 10 October 2012, available at http://www.hro.org/print/12020 [accessed 15th September 2013]

Presidential Council on Implementing National Priority Projects and Demographic Policy (2006) 'Kak rozhdalis' ideya natsionalnikh proektov?,' 16 March 2006, available at http://www.rost.ru/main/what/01/01.shtml [accessed 2nd August 2013]

Putin, V (2004) 'Annual Address to the Federal Assembly of the Russian Federation,' May 26 2004, available at http://www.kremlin.ru/eng/speeches/2004/05/26/1309_type70029type82912_71650.shtml

Putin, V (2012) 'Democracy and the quality of government,' Government of the Russian Federation, 6 February 2012, available at http://www.premier.gov.ru/eng/events/news/18006/ [accessed 1st September 2013]

Putin, V (2012) 'Meeting with regional human rights ombudspersons,' Official site of the President of Russia, available at http://eng.kremlin.ru/transcripts/4299 [accessed 1st September 2013]

Putin, V (2014) 'Poslaniye Federalnomu Sobraniyu,' Official site of the President of Russia, available at http://kremlin.ru/events/president/news/47173 [accessed 5th May 2015] Reuters (2013) 'Council of Europe tells Putin of concern over Russian NGO law,' 20th May 2013, available at http://www.reuters.com/article/2013/05/20/us-russia-europe-ngosidUSBRE94J0S120130520 [accessed 11th November 2013] 
RFERL (2013) 'The Crackdown on NGOs in Russia,' 11th November 2013, available at http://www.rferl.org/section/crackdown-on-ngos-in-russia/3272.html [accessed 11th

November 2013]

RFERL (2006) 'Russia: U.S. Official Says New NGO Law Part Of Anti-democratic Trend,' 2 February 2006, available at http://www.rferl.org/content/article/1065352.html

Richter, J (2002) 'Promoting civil society? Democracy assistance and Russian Women's Organisations,' Problems of Post Communism, Vol.49:1, pp. 30-41

RIA Novosti (2013) 'Inklyusivnoye obravovaniye v Rossii,' available at http://ria.ru/disabled_know/20130830/959635715.html [accessed 5th May 2015]

Richter, J (2009) 'The Ministry of Civil Society? The Public Chambers in the Regions,' Problems of Post-Communism, Vol:56:6, pp.7-20

Rigina, N (2013) ‘Opyt sotrudnichestva Blagotvoritnelnovo fonda 'Downside Up' s regionalnymi gosudarstvennami i nepravitelstvennimi strukturami po sozdaniyu uslovii dlya kompleksnovo medico-sozialnovo i psikholovo-pedagogicheskovo soprovozhdeniya semyei, vospityvayushikh detyei s sindromom Downa' in Vetrov, Yefremov et al (eds.) Analiticheskii Sbornik,, Ministerstvo Ekonomicheskovo Razvitiya Rossiiskoi Federatsii, available at http://grany-center.org/sites/default/files/files/page/analit_sbornik.pdf [accessed 22nd April 2015]

Rivkin-Fish, M (2010) 'Pronatalism, Gender Politics, and the Renewal of Family Support in Russia: Toward a Feminist Antrhopology of 'Maternity Capital',' Slavic Review, Vol.69:3, pp.701-724

Roudik, P (2007) 'Russian Federation: Children's Rights: International Law and National Laws and Practice,' Law Library of Congress, available at http://www.loc.gov/law/help/child-rights/russia.php

Sajo, A (1996) 'Rights in Post-Communism,' in Sajo, A (ed.) Western Rights? PostCommunist Application, The Hague: Kluwer Law International

Sakwa, R (2008) 'Putin's Leadership: Character and Consequences,' Europe-Asia Studies, Vol.60:6, pp.879-897

Salmenniemi, S (2010) 'Struggling for Citizenship: Civic Participation and the state in Russia,' Demokratizatsiya, Vol.18:4, pp.309-328

Schmitter, P (1985) 'Neo Corporatism and the state' in Grant, W (ed.) The Political Economy of Corporatism, New York: St. Martin's

Stanovaya, T (2014) '2015: Prinuzhdeniye k peremenam,' Politcom.ru, 29th December 2014, available at http://www.politcom.ru/18452.html [accessed 7th Jan 2015] 
Stat'ya 7, Glava 1, Konstitutsiya Rossiiskoi Federatsii [Article 7, Chapter 1, Constitution of the Russian Fderation], 1993, available at http://constitution.garant.ru/rf/chapter/1/\#block_1000 [accessed 30th March 2014]

Tarasenko, A (2013) 'Анализ практик поддержки СО НКО Санкт-Петербурга по данным реестра получателей госурдарственной поддержки,'

Tarasenko, A and Kulmala, M (2014) '”We are the electorate!" Russian Veterans' Organizations' Resistance to the Liberalization of Social Support,' Paper presented at the $14^{\text {th }}$ Annual Aleksanteri Conference 'Restructuring the State and Society in Russia, 22-24 ${ }^{\text {th }}$ October

Valenti, S (2010) 'The Role of the Ombudsman in the Defence of Social Rights in Times of Economic Crisis,' Workshop Debriefing Paper, Joint EU-Council of Europe Project, available at http://unipd-centrodirittiumani.it/en/pubblicazioni/The-role-of-the-ombudsmanin-the-defence-of-social-rights-in-times-of-economic-crisis/952

Wellman, C (1982) Welfare Rights, New Jersey: Rowman and Allanheld

Wengle, S and Rasell, M (2008) The monetisation of L'goty: changing patterns of welfare politics and provision in Russia, Europe-Asia Studies, Vol.60:5, pp. 739-756

Yershov, Y (2012) 'Doktrina Putina-1,' Polit.ru, 22 October 2012, available at http://www.polit.ru/article/2012/10/22/gontmakher/ [accessed 5th September 2013] 